\title{
Ensifer adhaerens gen. nov., sp. nov.: a Bacterial Predator of Bacteria in Soil $\dagger$
}

\author{
L. E. CASIDA, JR. \\ Department of Microbiology, Pennsylvania State University, University Park, Pennsylvania 16802
}

\begin{abstract}
A bacterial predator of bacteria in soil is described. This gram-negative predator was previously designated strain A. It is not an obligate predator, for it grows in the absence of host cells on a variety of media, including a medium composed of Noble agar in distilled water. It does not hydrolyze agar. The presence of host cells causes an overall increase in the growth of strain A on Noble agar but, except for tracking, does not do so on nutritionally richer media. During growth on most media in the presence of host cells, such as cells of Micrococcus luteus, strain A attaches in a picket fence arrangement to the host cells. Lysis of the host cells ensues if the $\mathrm{pH}$ of the environment remains approximately in the range from 6.0 to 6.5. At higher $\mathrm{pH}$ values, tracking and attachment occur, but without lysis of the host cells. A factor that diffuses through agar and causes lysis was detected emanating from strain A during growth on a nutritionally dilute medium. Strain A was shown to multiply by budding at one pole of the cell, followed by asymmetric polar growth and binary fission. Additional morphological and biochemical characteristics of strain A are presented. A new genus, Ensifer, is proposed for this bacterium. The type species is Ensifer adhaerens sp. nov., and strain A (= ATCC 33212) is the type strain of this species.
\end{abstract}

Casida (2) described the predatory activity in soil of an indigenous gram-negative bacterium which was designated strain A. This organism was one of the initial two bacterial predators that multiplied in response to Micrococcus luteus cells placed in the soil. Strain A attached to both the $M$. luteus cells and the other predator. Attack by these predators resulted in lysis of the $M$. luteus cells before known types of predators of bacteria could develop to any extent. Strain A was isolated and was found to attach to and lyse $M$. luteus cells in the laboratory. Strain A was not an obligate predator, however, and it was not nutritionally fastidious in the absence of host cells. It demonstrated the gyrating and tumbling motility that had been observed in soil.

In this paper I describe the morphology and growth cycle of strain A. The attachment of this strain to host cells is shown, and its lysis of $M$. luteus cells is evaluated. In addition, several of the biochemical and other characteristics of strain $\mathrm{A}$ are described. Based on this information, I propose that strain A should be designated as a member of a new species and genus.

\section{MATERIALS AND METHODS}

Media and tests. Unless otherwise stated, incubation was at $27^{\circ} \mathrm{C}$. The media used for strain $\mathrm{A}$ were as follows. Noble agar contained $1.5 \%$ Noble agar (Difco

† Paper 5896 in the journal series of the Pennsylvania Agriculture Experiment Station.
Laboratories, Detroit, Mich.) in distilled water. The agar addition to most other media was $1.5 \%$ agar (Difco). Dilute heart infusion (Difco) broths and agars were prepared at concentrations ranging from one-half to $1 / 100$ th the recommended strength. If needed, additional buffering capacity was supplied by adding $0.1 \%$ $\mathrm{KH}_{2} \mathrm{PO}_{4}$ and adjusting the $\mathrm{pH}$ to 6.0 with $\mathrm{KOH}$. Soil extract agar contained $20 \%$ soil extract and $80 \%$ tap water. The soil extract was obtained by autoclaving 1 $\mathrm{kg}$ of soil in 1 liter of distilled water for $30 \mathrm{~min}$, followed by combinations of filtration and a freezethaw cycle to yield a clear filtrate. Synthetic medium contained $0.1 \%$ glucose, $0.1 \% \quad \mathrm{NH}_{4} \mathrm{NO}_{3}, 0.1 \%$ $\mathrm{KH}_{2} \mathrm{PO}_{4}, 0.1 \% \mathrm{MgSO}_{4} \cdot 7 \mathrm{H}_{2} \mathrm{O}, 0.1 \% \mathrm{NaCl}$, and $0.1 \% \mathrm{~L}-$ glutamic acid $(\mathrm{pH} 7.0)$. When required, Noble agar was used to solidify this medium. The blood agar used for hemolysis evaluations was Trypticase soy agar (blood agar base; BBL Microbiology Systems, Cockeysville, Md.) containing 5\% defibrinated sheep blood. PYG broth contained $0.5 \%$ peptone, $0.1 \%$ yeast extract, and $0.1 \%$ glucose. For the Hugh-Leifson test for oxidative versus fermentative metabolism, the medium and procedures of Hugh and Leifson (4) were used. The aerobic nature of the organism was determined by using agar shake and stab tubes containing 1/10thstrength heart infusion agar. In trials for growth in the light $\left(50 \mu \mathrm{E} \cdot \mathrm{m}^{-2} \cdot \mathrm{s}^{-1}\right)$ and dark, stabs and slants of fullstrength heart infusion agar (2\% agar) and full (rubber stoppers) and partially filled bottles of this medium as a broth were used; the stabs were $5 \mathrm{~cm}$ deep, with a $0.5-\mathrm{cm}$ overlay of similar agar medium.

Nitrification ability was evaluated in shaken and stationary cultures in synthetic medium broth containing $0.1 \%\left(\mathrm{NH}_{4}\right)_{2} \mathrm{SO}_{4}$ instead of $\mathrm{NH}_{4} \mathrm{NO}_{3}$. Denitrification was tested with shaken and stationary cultures in 
synthetic medium $\left(0.1 \% \mathrm{NaNO}_{3}\right)$ and in stationary cultures in $1 / 10$ th- and full-strength heart infusion broths containing $0.1 \% \mathrm{NaNO}_{3}$. Nitrite was detected by the procedure of Montgomery and Dymock (6) with $\mathrm{K}_{2} \mathrm{SO}_{4}$ deleted from the sulfanilic acid solution. When samples were negative for nitrite, fresh samples were incubated for $15 \mathrm{~min}$ at room temperature with 20 mesh granular $\mathrm{Zn}$ and then tested for nitrite. Cells to be used for acetylene reduction trials were grown in shaken synthetic medium broth (complete medium) and on synthetic medium agar lacking combined nitrogen components. Synthetic medium broth lacking combined nitrogen was used in the reduction trial itself. Synthetic medium containing combined nitrogen and agar was used for determining the effect of acetate on glucose utilization and for growing cells for determinations of the guanine-plus-cytosine content of the deoxyribonucleic acid. Cells examined by electron microscopy were grown on either synthetic medium agar or dilute heart infusion broth (shaken culture) or agar.

Starch hydrolysis was determined on soil extract agar and 1/10th-strength heart infusion agar (both supplemented with $0.1 \%$ starch) and on starch agar (Difco). In the tests for acetate inhibition and utilization of various carbon sources, soil extract agar with additions at concentrations of $0.1 \%(\mathrm{pH} \mathrm{7.1)}$ was used. Strain A grew only slowly on this medium without an added carbon source. One-tenth-strength heart infusion agar was used for the tests for $\mathrm{NaCl}$ inhibition, catalase reaction, growth temperature, and motility (stabs, $0.5 \%$ agar). The observation of flagella by electron micrography and of motility by phase-contrast microscopy was used to determine motility.

Plates with perpendicular streaks of strain A and host organism were prepared as described previously (2). Plates containing Noble agar medium or $1 / 100$ thstrength heart infusion agar were observed after incubation, and approximately $2.0 \mathrm{ml}$ of double-strength heart infusion agar (1.5\% agar) was applied to open areas on the agar surface not containing growth. The plates were then incubated to detect any growth of the host cells. Lysis of $M$. luteus cells on plates was detected by (i) observing the disappearance of the $M$. luteus cells as tracking progressed, (ii) phase-contrast microscopy of a sample from within the lysed area, (iii) streaking on 1/10th-strength heart infusion agar of a sample taken from the lysed area, and (iv) use of a delayed addition of double-strength heart infusion agar (see above).

Slide culture. A culture of strain A was made on a slide ( 38 by $75 \mathrm{~mm}$ ) with a circular area (diameter, 20 $\mathrm{mm}$ ) removed from its center. This area was covered by a no. 1 cover glass ( 35 by $50 \mathrm{~mm}$ ) sealed to the slide with petrolatum. A loopful of a broth culture was spread across the exposed underside of this cover glass, and 1 or 2 drops of full-strength heart infusion agar was added and allowed to solidify. Additional medium was added to almost fill the well in the slide. A piece of 1.0-mil polyethylene (from a painter's plastic drop cloth) was placed across the surface of a microscope stage so that it covered the stage and extended beneath the mechanical stage. The surface of the polyethylene was sterilized by swabbing with alcohol. The slide, prepared as described above, was then handled and viewed in the normal manner for phasecontrast microscopy.
Electron microscopy. One drop of a cell suspension was placed onto a grid coated with carbon over Parlodion. After $2 \mathrm{~min}$, most of the fluid was removed by absorbing it with a wedge of filter paper. One drop of $0.5 \%$ aqueous uranyl acetate or phosphotungstic acid (to provide negative contrast) was placed over the remaining fluid. After $2 \mathrm{~min}$, most of this fluid was removed by absorption, and the grid was allowed to air dry. Samples for thin sectioning were fixed in $1 \%$ $\mathrm{OsO}_{4}$ in Kellenberger buffer (5) overnight at room temperature. These samples were then stained in $0.5 \%$ uranyl acetate in Kellenberger buffer for $2 \mathrm{~h}$, dehydrated through a graded ethanol series, and embedded in Spurr low-viscosity resin (8). Sections were cut with an LKB Ultratome III ultramicrotome equipped with a Du Pont diamond knife and were picked up on Parlodion-carbon-coated 200-mesh copper grids. These sections were poststained in $0.5 \%$ uranyl acetate in methanol for $15 \mathrm{~min}$, followed by $0.4 \%$ lead citrate for $1 \mathrm{~min}(7)$, and they were viewed with a Philips model EM-300 electron microscope operated at $80 \mathrm{kV}$.

\section{RESULTS AND DISCUSSION}

Cell multiplication. The division process of strain $\mathrm{A}$ is shown in Fig. 1. A modified slide culture technique (see above) was devised to provide enough oxygen for cell multiplication. Growth was initiated by budding at one end of a cell, and the bud then elongated (Fig. 2) to give asymmetric polar growth. This growth usually widened to equal the diameter of the mother cell (Fig. 1). The daughter cell eventually separated from the mother cell by binary fission (Fig. 3). Either the mother and daughter cells were the same size, or the daughter cell was smaller. Measurements of cell size from electron micrographs (Fig. 4) showed that some of the nonattached daughter cells were 20 to $30 \%$ smaller (length or width or both) than the nondividing mother cells. There was no tube or filament between the mother and daughter cells at the time of binary fission. After fission, growth resumed as new buds at the newly formed poles of both the mother and daughter cells. There did not seem to be any requirement for a rest or maturation period before growth resumed. Bud formation did not always occur at the end of the cell. In old cultures, buds that had formed from the side of a mother cell were sometimes observed.

The budding and division processes of strain A somewhat resemble those described by Eckersley and Dow (3) for Rhodopseudomonas blastica. However, the latter organism is photosynthetic and grows anaerobically in the light; also, it divides only when the mother and daughter cells are of equal size. The daughter cell has to undergo an obligate period of maturation before it initiates growth.

Morphology and attachment. A whole-cell preparation of strain A negatively stained with uranyl acetate is shown in Fig. 5. With this stain, 

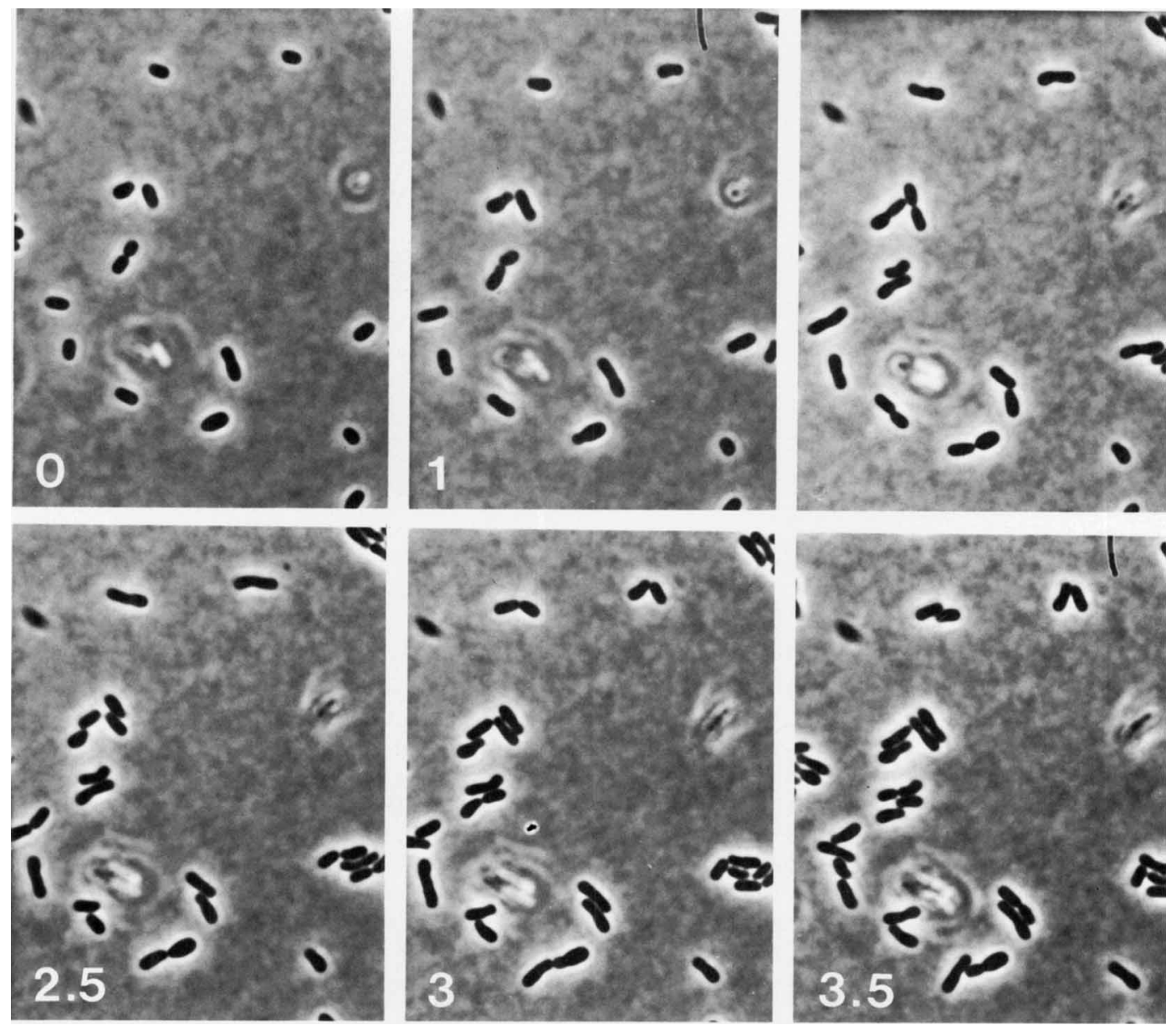

FIG. 1. Growth of strain A on full-strength heart infusion agar. The numbers indicate the length of incubation (in hours). Phase-contrast microscopy of a slide culture. $\times 1,452$.

darkly stained material was often observed as a bar along the side of the cell. This bar became wider near one or both poles of the cell. When cells of strain A attached to host cells, such as cells of $M$. luteus, this bar often extended between the strain A cell and the $M$. luteus cell (Fig. 6). The composition of this bar is not known, however, because it has not been unequivocally located in sectioned material and because of the presence of excess slime on the cells. Also, this bar was not readily apparent in whole-cell preparations of strain A that were negatively stained with phosphotungstic acid instead of uranyl acetate.

Figure 6 shows a strain A cell attached to an $M$. luteus cell after the two organisms were merely mixed together in water and allowed to stand for approximately $30 \mathrm{~min}$. In contrast, when strain A was grown in the presence of $M$. luteus on an agar medium, large numbers of strain A cells attached to M. luteus cells (Fig. 7).
These strain A cells were arranged side by side, closely packed, in a picket fence arrangement. If the prevailing nutritive and $\mathrm{pH}$ conditions (either in soil or on laboratory media) were satisfactory, this arrangement eventually resulted in the death and lysis of the $M$. luteus cells.

Tracking and lysis. Casida (2) described the ability of a streak of strain A cells on an agar medium to track an intersecting perpendicular streak of $M$. luteus cells. Thus, the strain A cells advanced through and over the $M$. luteus cells in their streak without deviating from the streak. In this study, I found that this tracking occurred to varying degrees on most media regardless of the nutritive level or $\mathrm{pH}$ of the media. However, it was necessary that the streaks of strain A and $M$. luteus actually intersected. No tracking occurred if the $M$. luteus streak came up to but did not touch the strain A streak.

Tracking was not necessarily accompanied by lysis of the M. luteus cells. For lysis to occur, it 


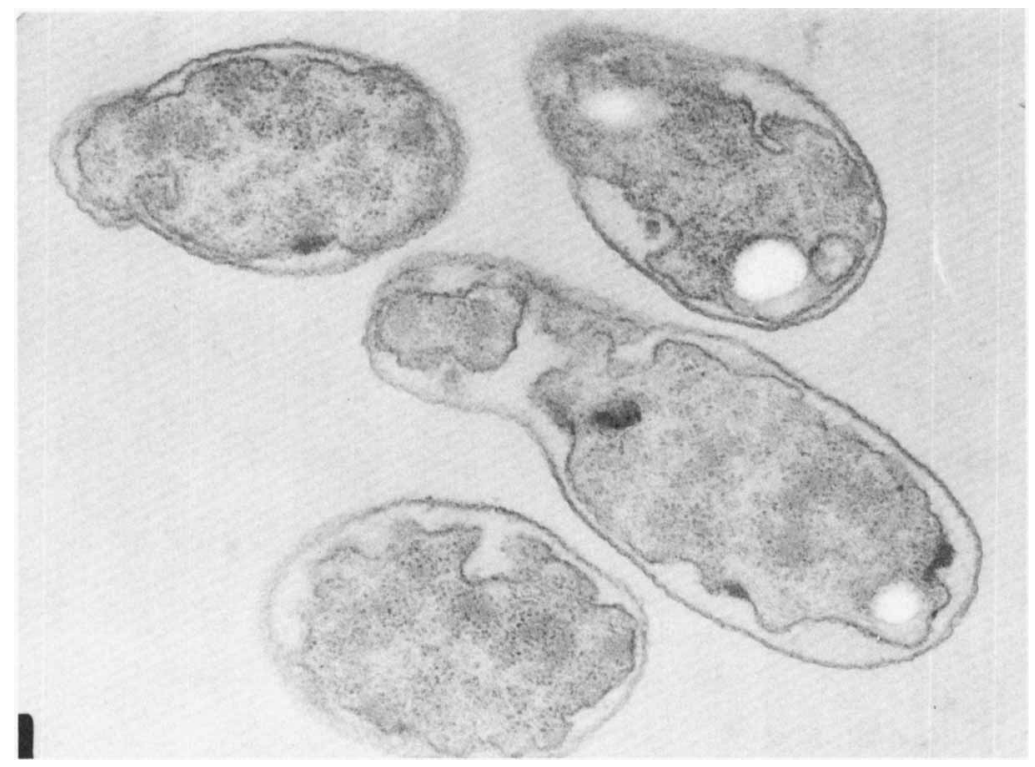

FIG. 2. Bud formation and growth of strain A. $\times 31,450$.

was necessary for the medium to be adjusted initially to a pH of 6.0 to 6.5 (pH 6.0 was best) and for the $\mathrm{pH}$ not to rise above this range during the first few days of growth of the organisms. Nutritionally rich media, such as $1 / 10$ thstrength heart infusion agar buffered at $\mathrm{pH} 6$ and full-strength heart infusion agar adjusted to $\mathrm{pH}$ 6.0, showed tracking over a distance (e.g., 19 $\mathrm{mm}$ ) of the $M$. luteus streak, with $M$. luteus cell lysis occurring for only part of this distance (e.g., $7 \mathrm{~mm}$ ). On a medium of low nutritive value, such as $1 / 100$ th-strength heart infusion agar containing $0.1 \%$ glucose, an initial $\mathrm{pH}$ adjustment or inclusion of a buffer was not necessary. Slight production of acidity from the sugar during growth kept the $\mathrm{pH}$ within the $\mathrm{pH}$ range

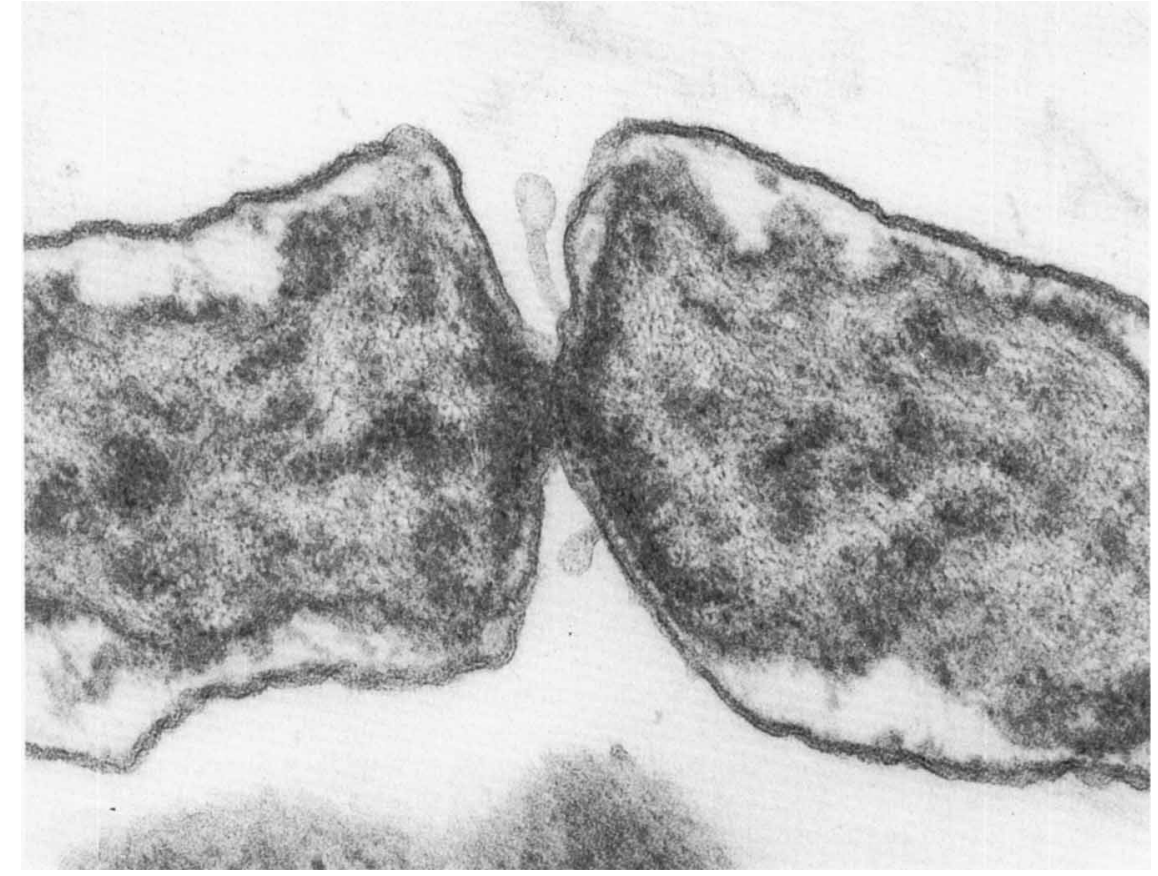

FIG. 3. Separation of daughter cell from mother cell by binary fission. $\times 88,500$. 


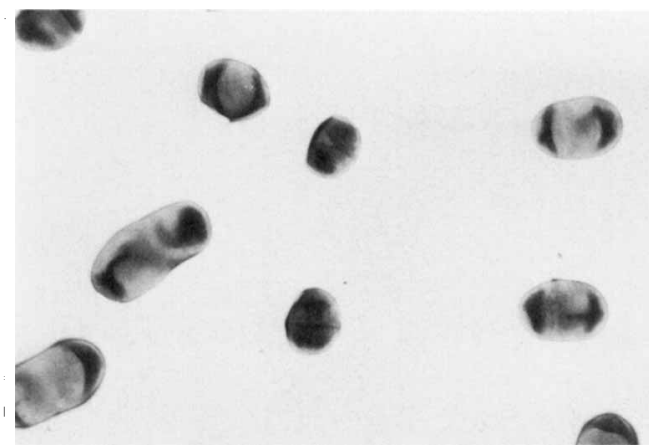

FIG. 4. Variation in cell size of nondividing strain A cells. $\times 4,760$.

from 6.0 to 6.5 for a long enough time. With this medium, a diffusible lytic factor emanating from strain A could be detected. The distance of lysis of the $M$. luteus cells exceeded the distance of tracking (e.g., $33 \mathrm{~mm}$ for lysis and $11 \mathrm{~mm}$ for tracking). Inclusion of $0.01 \%$ yeast extract in the medium did not affect the results. When the $M$. luteus and strain A streaks did not intersect (3 to 4-mm gap), the inhibition of $M$. luteus was as described above, but tracking did not occur. On this medium, lysis was apparent both before and after a belated agar surface addition of doublestrength heart infusion agar to check for the

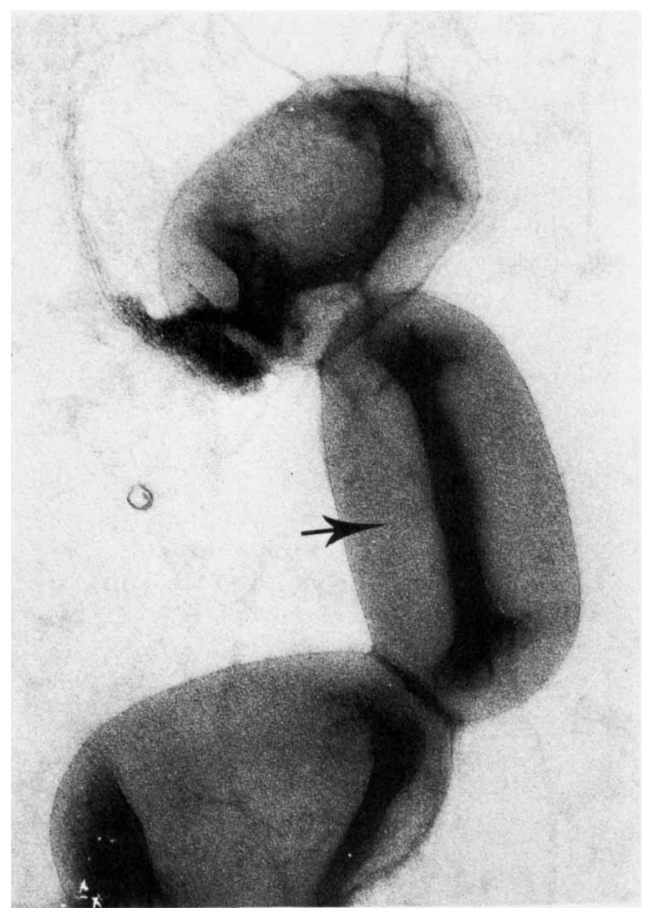

FIG. 5. Strain A cells stained with uranyl acetate showing darkly stained bar (arrow) along the side of the cell. $\times 30,000$. presence of any viable $M$. luteus cells within the lysis area.

Strain A was not an obligate predator. It grew well on most media in the absence of potential host cells. In fact, except for the occurrence of tracking, the overall growth of strain A usually did not increase as a result of tracking or lysis of $M$. luteus cells. However, some increased growth of strain A did occur when these organisms were placed on Nobel agar with or without $0.1 \%$ glucose. Therefore, it appears that the only benefits of this interaction to strain A occurred on a medium of very low nutritive value. This is comparable to the presumed low nutrient availability that occurs in soils that have not recently received organic matter. In soil, the strain A cells would attach to host cells so that even small amounts of lytic factor produced under these conditions could be used effectively in lysing the host cells.

Proposed taxonomy. The characteristics of strain A seem to place it in part 4, (budding and/ or appendaged bacteria) of division II (the bacteria) in Bergey's Manual of Determinative Bacteriology, 8th ed. (1). However, strain A differs significantly from all of the genera in part 4 . Therefore, I propose that a new genus, Ensifer, be established for this bacterium. The characterization of this genus follows.

Ensifer gen. nov. (L. adj. ensifer sword bearing; M. L. mas. noun Ensifer sword bearer). Gram negative, but may stain poorly. Rods 0.7 to 1.1 by 1.0 to $1.9 \mu \mathrm{m}$, occurring singly or in pairs. Motile by means of a tuft of three to five flagella that are attached subterminally.

Reproduction by budding at one end of the cell, with the bud then elongating to give asymmetric polar growth. Separation of the cells occurs by binary fission. After fission, growth resumes as new buds at the newly formed poles of both the mother and daughter cells.

Attaches end-wise to various living grampositive and gram-negative host bacteria. There is no specialized terminal structure on the cell for attachment purposes. Rosettes are not formed. Depending on the $\mathrm{pH}$ ( $\mathrm{pH} 6$ is best), the nutritive level of the environment, and the species of host cell, the host cells may be killed, and often they are also lysed. M. luteus is a good host for demonstrating this phenomenon. Attachment to and lysis of bacterial cells occur naturally in soil and in vitro with pure cultures. Not an obligate predator and not fastidious in its nutritional requirements. On agar media produces a diffusible factor for lysis of host cells.

After 6 days, colonies 10 to $15 \mathrm{~mm}$ in diameter are produced on heart infusion agar prepared at $1 / 10$ th the recommended strength. The colonies are grayish white, convex, circular with undulate margins, slimy, moist, and opaque; they 


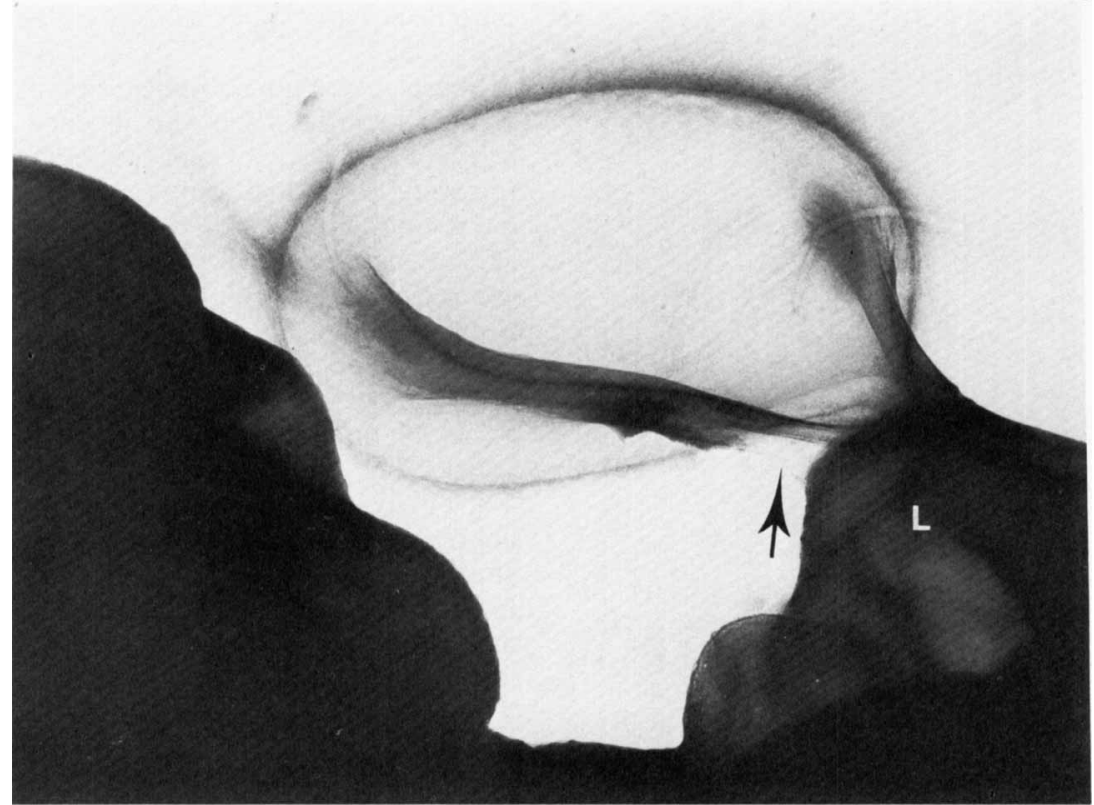

FIG. 6. Bar material (arrow) as in Fig. 6, extending between strain A cell and darkly stained M. luteus cell (L). $\times 50,900$.

may appear almost translucent due to excessive slime production. Growth on agar slants is abundant, opaque, grayish white, smooth, flat, slimy, and moist.

Optimal growth occurs at around $27^{\circ} \mathrm{C}$; good growth occurs at 20 and $37^{\circ} \mathrm{C}$. Aerobic; does not grow anaerobically in the presence of light. Pellicle and sediment (little turbidity) are produced in PYG broth. Weakly catalase positive. Nitrate and nitrite are reduced. Nitrification is

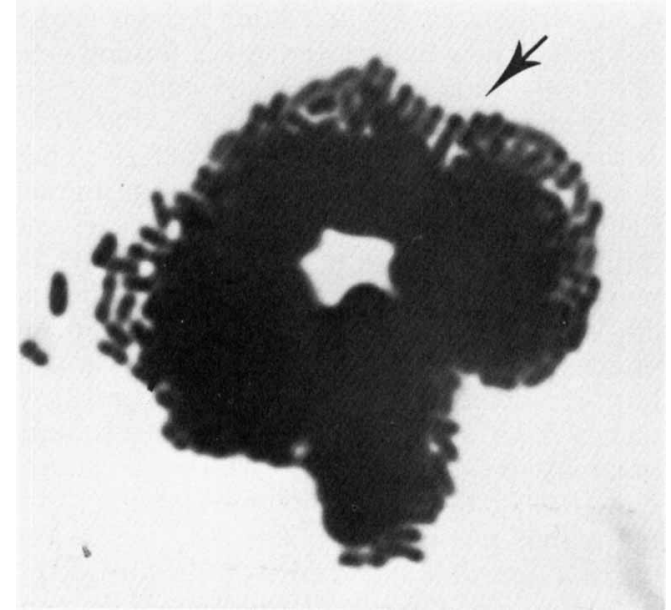

FIG. 7. Attachment of strain A cells (arrow) around $M$. luteus (darkly stained cell clumps) during growth on 1/10-strength heart infusion agar. Crystal violet stain. $\times 3,123$. negative for ammonia and nitrite. Acetylene is not reduced. The metabolism (4) of glucose and galactose is oxidative; no growth occurs under petrolatum; in the absence of petrolatum, gas is not produced, and only trace amounts of acid, if any, are produced.

Definite but slow growth occurs during sequential transfers on $1.5 \%$ Noble agar in distilled water. Host cells are not required, and agar is not hydrolyzed. This growth is equivalent to that obtained on soil extract agar. Grows well on most media. A good synthetic medium contains $0.1 \%$ glucose, $0.1 \% \mathrm{NH}_{4} \mathrm{NO}_{3}, 0.1 \% \mathrm{KH}_{2} \mathrm{PO}_{4}$, $0.1 \% \mathrm{MgSO}_{4} \cdot 7 \mathrm{H}_{2} \mathrm{O}, 0.1 \% \mathrm{NaCl}, 0.1 \%$ L-glutamic acid, and $1.5 \%$ agar $(\mathrm{pH} \mathrm{7.0)}$. Utilizes a variety of organic carbon sources, including glucose, galactose, mannose, rhamnose, xylose, mannitol, sorbitol, glycerol, L-glutamic acid, Lalanine, L-asparagine, and L-glutamine. Acetate is used only slowly and does not inhibit glucose utilization. Grows on pure gelatin without hydrolysis. Starch is not hydrolyzed. Growth is inhibited by $4 \% \mathrm{NaCl}$; good growth is obtained with $2 \% \mathrm{NaCl}$.

Good growth occurs on blood agar; nonhemolytic. Good growth also occurs on Desoxycholate agar; initially the growth is whitish purple and then changes to buff. Does not survive $30 \mathrm{~s}$ of heating in tap water at $71^{\circ} \mathrm{C}$.

Isolated from soil. Attaches to other bacteria in soil and sometimes lyses them. Can be present (attached to the cells) in cultures of other bacteria isolated from soil; can be removed from 
these cultures by growth on media containing $4 \% \mathrm{NaCl}$.

The guanine-plus-cytosine content of the deoxyribonucleic acid is $67 \mathrm{~mol} \%$ (as determined by the thermal melting point) or $63 \mathrm{~mol} \%$ (as determined by buoyant density).

Ensifer adhaerens sp. nov. (L. adj. adhaerens adherent). Description as for the genus. Type species of the genus Ensifer. The type strain of $E$. adhaerens is strain A, a culture of which has been deposited with the American Type Culture Collection under the number ATCC 33212. The description of the type strain is the same as that given above for the genus and species. Two variants have been isolated from cultures of this organism. These variants produce less slime, which results in smaller colonies and a drier and slightly whiter appearance of the colonies.

Futher comments. A strain of this bacterium that differs from strain A somewhat in its rate of attack on M. luteus cells but not in most other characteristics was isolated from the same soil as strain $\mathrm{A}$, but the soil had been incubated with added Bacillus subtilis spores instead of $M$. luteus cells. A culture of this strain (strain 7A) has been deposited with the American Type Culture Collection under the number ATCC 33499. Strain 7A can be differentiated from strain $\mathrm{A}$ by its growth on Desoxycholate agar; strain 7A growth remains purple throughout 10 days and then becomes whitish purple.

\section{ACKNOWLEDGMENTS}

This work was supported by grant DAAG29-79-G-0043 from the U.S. Army Research Office.
I thank D. H. Bernitt for technical assistance and Kang Chien Liu, T. Doman, and D. L. Balkwill for electron microscopy assistance. The acetylene reduction trials were conducted by S. E. Stevens. W. D. Taylor determined the guanineplus-cytosine content of the DNA deoxyribonucleic acid.

\section{REPRINT REQUESTS}

Address reprint requests to: Dr. L. E. Casida, Jr., Department of Microbiology, Pennsylvania State University, S101 Frear Building, University Park, PA 16802.

\section{LITERATURE CITED}

1. Buchanan, R. E., and N. E. Gibbons (ed.). 1974. Bergey's manual of determinative bacteriology, 8th ed. The Williams \& Wilkins Co., Baltimore.

2. Casida, L. E., Jr. 1980. Bacterial predators of Micrococcus luteus in soil. Appl. Environ. Microbiol. 39:1035-1041.

3. Eckersley, K., and C. S. Dow. 1980. Rhodopseudomonas blastica sp. nov.: a member of the Rhodospirillaceae. J. Gen. Microbiol. 119:465-473.

4. Hugh, R., and E. Leifson. 1953. The taxonomic significance of fermentative versus oxidative metabolism of carbohydrates by various gram-negative bacteria. J. Bacteriol. 66:24-26.

5. Kellenberger, E., A. Ryter, and J. Sechaud. 1958. Electron microscope study of DNA-containing plasms. II. Vegetative and mature phage DNA as compared with normal bacterial nucleoids in different physiological states. J. Biophys. Biochem. Cytol. 4:671-687.

6. Montgomery, H. A. C., and J. F. Dymock. 1961. The determination of nitrite in water. Analyst (London) 86:414-416.

7. Reynolds, E. S. 1963. The use of lead citrate at high $\mathrm{pH}$ as an electron-opaque stain in electron microscopy. J. Cell Biol. 17:208-212.

8. Spurr, A. R. 1969. A low-viscosity epoxy resin embedding medium for electron microscopy. J. Ultrastruct. Res. 26:31-43. 